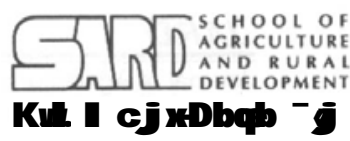

Available online at http: / / www.banglajol.info/index.php/jard

\title{
Nitrogen Use Efficiency of Wheat and Transplant Aman Rice under Bed Planting Method in Rice-Wheat Cropping System
}

\author{
M. I. U. MOLLAH ${ }^{1 *}$, M. S. U. BHUIYA ${ }^{2}$ \& A. KHATUN ${ }^{3}$ \\ ${ }^{1}$ Training Division, Bangladesh Rice Research Institute, Gazipur-1701, Bangladesh \\ ${ }^{2}$ Department of Agronomy, Bangladesh Agricultural University, Mymensingh-2202, Bangladesh \\ ${ }^{3}$ Rice Farming System Division, Bangladesh Rice Research Institute, Gazipur-1701, Bangladesh
}

\begin{abstract}
An experiment was conducted at the Bangladesh Rice Research Institute (BRRI) experimental farm, Gazipur and at farmer's field in Chuadanga during Rabi season 2001-02 (November - March) to Kharif-II season 2002 (June - November) to determine the effect of different doses of $N$ fertilizer on growth and yield of wheat and transplant Aman rice and to compare the $N$ use efficiency in bed planting and conventional method in rice-wheat cropping system. Bed planting with 0, 60, 80, 100 and $120 \mathrm{~kg}$ $\mathrm{N} \mathrm{ha} \mathrm{C}^{-1}$ and conventional (flat) method with 0 and $100 \mathrm{~kg} \mathrm{~N} \mathrm{ha}^{-1}$ were tested. The yields increase of wheat in bed planting with 80,100 and $120 \mathrm{~kg} \mathrm{~N} \mathrm{ha}^{-1}$ over $100 \mathrm{~kg} \mathrm{~N} \mathrm{ha}^{-1}$ in conventional method were 10-21, 20-29 and 23-38\%, respectively. For transplant Aman rice, bed planting with 80, 100 and 120 $\mathrm{kg} \mathrm{N} \mathrm{ha}^{-1}$ and conventional method with $100 \mathrm{~kg} \mathrm{~N}^{-1}$ produced statistically identical grain yield. Bed planting increased the grain number panicle ${ }^{-1}$ and reduced sterility of both wheat and transplant Aman rice. Nitrogen use efficiency such as partial factor productivity and agronomic efficiency were higher in bed planting than conventional method and it saved about $20 \% \mathrm{~N}$ without losing yield of wheat and transplant Aman rice.
\end{abstract}

Key words: Nitrogen use efficiency, rice, wheat and bed planting.

\section{INTRODUCTION}

Rice and wheat are the most important food crops in South Asia. About 60\% of the farming households live on less than $30 \%$ of global agricultural lands (Gupta et al., 2003) and approximately 240 million people in South Asia consume rice and/or wheat produced in rice-wheat system (Benites, 2001). Moreover, the annual productivity of the rice-wheat system in the IndoGangetic Plain (IGP) is small (5-7 t ha $\left.{ }^{-1}\right)$ compared with currently attainable (8-10 $\mathrm{t} \mathrm{ha}^{-1}$ ) and site potential (12-19 $\mathrm{t} \mathrm{ha}^{-1}$ ) yields (Aggarwal et al., 2000). In Bangladesh, rice covers about 10.5 million ha of land producing 26.5 million tons of grain and contributes over $90 \%$ of the total food grain production and wheat covers about 0.5 million ha of land producing 0.7 million tons of grain (BBS, 2007). The continuous cultivation of rice and wheat - two crops or more per year - has provided food and livelihoods for hundreds of thousands of rural and urban poor in South Asia. Now a crisis looms as the population is growing at more than $2 \%$ (nearly 24 millions additional mouth to feed) each year and agricultural land area dwindles and yield increase are leveling off (Hobbs, 2003). In order to grow more food from marginal and good quality lands, the quality of natural resource base

* Corresponding author: PSO, Training Division, BRRI, Gazipur-1701, Mobile: 01712034459, E-mail: miumollah@yahoo.com

(C) 2009 School of Agriculture and Rural Development, Bangladesh Open University, All rights reserved. 
must be improved and sustained. Efficiency of natural resources like, seed, fertilizer, water, fuel and labour require to be improved.

Bed planting in rice-wheat cropping system is a new method for improving resource use efficiency and increasing the yield. In this system, land is prepared conventionally and raised bed and furrows are prepared manually or using a raised bed planting machine. Crops are planted in rows on top of the raised beds and irrigation water is applied in the furrows between the beds. This system is often considered for growing high value crops that are more sensitive to temporary waterlogging stress. Wheat on raised bed though introduced in the IGP few years ago, the practice of rice on narrow raised bed introduced very recently (Connor et al., 2003b).

The application of high $\mathrm{N}$ rates may result in poor $\mathrm{N}$ uptake and low $\mathrm{N}$ use efficiency due to excessive $\mathrm{N}$ losses. Inefficient $\mathrm{N}$ use contributes to greater use of energy resources, increased production costs, and possible pollution of water by nitrates. Proper timing of $\mathrm{N}$ application and adequate $\mathrm{N}$ rates are critical in meeting plant needs and in improving $\mathrm{N}$ use efficiency (LimonOrtega et al., 2000). Latest research activities in India and Pakistan indicates that bed planting of wheat in rice-wheat system reduces $\mathrm{N}$ loses and improved fertilizer use efficiency (Gupta et al., 2000; Hobbs and Gupta, 2003; Connor et al., 2003a) but a little information is available on bed planting of rice and in Bangladesh it is very new. Therefore, the study was undertaken to determine the effect of $\mathrm{N}$ dose on the growth and yield of wheat and transplant Aman rice under bed planting and to compare $\mathrm{N}$ use efficiency of wheat and transplant Aman rice in bed planting with conventional methods in rice-wheat cropping system.

\section{MATERIALS AND Methods}

The experiment was conducted at the Bangladesh Rice Research Institute (BRRI) experimental farm, Gazipur during Rabi season 2001-02 (November - March) to Kharif-Il season 2002 (June November) and simultaneously at farmer's field in Chuadanga. The soil of the experimental plot at Gazipur was clay loam with $\mathrm{pH} 6.23$ and at Chuadanga it was silty loam with $\mathrm{pH} 7.30$. Bed planting with 0 (Bed 0, control), 60 (Bed 60), 80 (Bed 80), 100 (Bed 100), and 120 (Bed 120) kg N ha ${ }^{-1}$ and conventional (flat) method with 0 (Flat 0 , control) and 100 (Flat 100 , recommended) $\mathrm{kg} \mathrm{N}^{-1}$ were tested for both wheat and transplant Aman rice. The experiment was laid out in a randomized complete block design with three replications for both the crops at both the locations. The unit plot size was $28 \mathrm{~m}^{2}(7 \mathrm{~m} \times 4 \mathrm{~m})$ and $70 \mathrm{~m}^{2}(10 \mathrm{~m} \times 7 \mathrm{~m})$ at Gazipur and Chuadanga, respectively.

\section{Crop management for wheat}

The wheat variety Kanchan was used in both the locations and the seed rate was $120 \mathrm{~kg} \mathrm{ha}^{-1}$. Seeds were treated with Viatvax-200 at the rate of three gram $\mathrm{kg}^{-1}$ seed. Seventy-centimeter wide raised beds (40 cm top and $30 \mathrm{~cm}$ furrow) were made manually by spade following the conventional land preparation. The height of beds was $15 \mathrm{~cm}$.

Phosphorus, K, S and Zn were applied at the rates of 36, 25, 20 and $4 \mathrm{~kg} \mathrm{ha}^{-1}$, respectively. The $\mathrm{N}$ rates were according to the treatments mentioned earlier. Two-thirds $\mathrm{N}$ and whole $\mathrm{P}, \mathrm{K}, \mathrm{S}$ and $\mathrm{Zn}$ fertilizers were applied at the time of final land preparation. The remaining one-third $\mathrm{N}$ was topdressed at 19 days after sowing at crown root initiation i.e. at three leaf stage. This was followed by irrigation. For the treatments with bed planting, $\mathrm{N}$ was topdressed on the top of beds only. Seeds were sown in rows in both bed and conventional methods. For beds, seeds were sown in two rows bed ${ }^{-1}$. For conventional method, row-to-row distance was $20 \mathrm{~cm}$. In the row, seeds were sown continuously and covered properly with soil. The dates of sowing were 22 and 17 November in Gazipur and Chuadanga, respectively. Other recommended crop management practices were followed. Wheat was harvested on 17 and 15 March in Gazipur and Chuadanga, respectively. Grain yield and yield components data were collected at maturity.

\section{Crop management for transplant Aman rice}

Transplant Aman rice variety BRRI dhan30 was used in both the locations. The beds prepared for wheat were kept intact for rice in both the locations. Therefore, rice on bed was grown on zero 
tillage condition. After harvesting of wheat the lands were remained fallow in Kharif-I season in both the sites. Glycel (41\% Glyphosate) @ $3.7 \mathrm{~L} \mathrm{ha}^{-1}$ was applied 15 days before transplanting for killing weeds. The conventional tillage plots were prepared by puddling.

Phosphorus, K, S and Zn were applied at the rates of 20,35, 10 and $4 \mathrm{~kg} \mathrm{ha}^{-1}$, respectively. The $\mathrm{N}$ rates were according to the treatments. In the conventional treatment, the whole of $\mathrm{P}, \mathrm{K}, \mathrm{S}$ and $\mathrm{Zn}$ were applied at final land preparation and in bed planting treatments, these basal doses were applied on the top of the beds before transplanting. Urea was topdressed in three equal splits at 15, 30 and 50 days after transplanting. Thirty-day old seedlings were transplanted on 16 and 20 July 2002 in Gazipur and Chuadanga, respectively. Two to three seedlings were transplanted in rows in both bed and conventional methods. The spacing was $20 \mathrm{~cm} \times 20 \mathrm{~cm}$. For the beds, seedlings were transplanted in two rows at $20 \mathrm{~cm}$ apart on the top of beds keeping $10 \mathrm{~cm}$ at each edge. Irrigation water was applied between the furrows of bed one day before transplanting to make the soil soft. Other recommended crop management practices were followed. In Gazipur, rice was harvested on 04-07 November and in Chuadanga it was harvested on 10-15 November. Grain yield, yield components and other growth parameter data were collected at maturity.

Partial factor productivity (PFP) and Agronomic efficiency (AE) were calculated to compare $\mathrm{N}$ use efficiency of wheat and rice. The PFP, grain yield per quantity of $\mathrm{N}$ applied was calculated as follows:

$$
\mathrm{PFP}=\frac{\mathrm{Y}}{\mathrm{N}_{\mathrm{r}}}
$$

Where, $\mathrm{Y}=$ Grain yield with applied $N\left(\mathrm{~kg} \mathrm{ha}^{-1}\right)$ and $\mathrm{N}_{\mathrm{r}}=$ Rate of $\mathrm{N}$ fertilizer application $(\mathrm{kg}$ ha $\left.{ }^{1}\right)$. The $A E$, grain yield increase from applied $\mathrm{N}$, was calculated as follows:

$$
\mathrm{AE}=\frac{\Delta \mathrm{Y}}{\mathrm{N}_{\mathrm{r}}}
$$

Where, $\Delta \mathrm{Y}=\mathrm{Y}-\mathrm{Y}_{0}, \Delta \mathrm{Y}=$ Increase in grain yield with $\mathrm{N}$ fertilizer $\left(\mathrm{kg} \mathrm{ha}^{-1}\right), \mathrm{Y}=$ Grain yield with $\mathrm{N}$ fertilizer $\left(\mathrm{kg} \mathrm{ha}^{-1}\right), \mathrm{Y}_{0}=$ Grain yield without $\mathrm{N}$ fertilizer $\left(\mathrm{kg} \mathrm{ha}^{-1}\right)$ and $\mathrm{N}_{\mathrm{r}}=$ Rate of $\mathrm{N}$ fertilizer application ( $\left.\mathrm{kg} \mathrm{ha}^{-1}\right)$.

\section{Results AND Discussion}

\section{Grain yield and yield components of wheat}

Effect of different nitrogen treatments on grain yield and yield components of wheat were significant in both the locations. In Gazipur, N application at the rate of 80,100 and $120 \mathrm{~kg} \mathrm{ha}^{-1}$ under bed planting system gave similar yield which were significantly higher than rest of the treatments (Table 1). The yield increase in bed planting with 80,100 and $120 \mathrm{~kg} \mathrm{~N}^{-1}$ over $100 \mathrm{~kg} \mathrm{~N}^{-1}$ in conventional were 21, 29 and 38\%, respectively. The treatments with $100 \mathrm{~kg} \mathrm{~N} \mathrm{ha}^{-1}$ in flat and 60 $\mathrm{kg} \mathrm{N} \mathrm{ha}^{-1}$ in bed planting gave statistically identical grain yield. This result indicated that grain yield of wheat could be increased by bed planting method over conventional method using same dose of $\mathrm{N}\left(100 \mathrm{~kg} \mathrm{ha}^{-1}\right)$ or even by lower dose $\left(80 \mathrm{~kg} \mathrm{ha}^{-1}\right)$ and without losing yield, $40 \mathrm{~kg} \mathrm{~N} \mathrm{ha}^{-1}(40 \%)$ could be saved. The highest grain yield was achieved with $120 \mathrm{~kg} \mathrm{~N} \mathrm{ha}^{-1}$ in bed planting (3.05 $\mathrm{t}$ ha $\left.{ }^{1}\right)$. In Chuadanga, the grain yield under different treatments showed similar trend. The grain yield in bed with 80,100 and $120 \mathrm{~kg} \mathrm{~N}^{-1}$ were also similar. Though the conventional method with $100 \mathrm{~kg}$ $\mathrm{N}$ ha ${ }^{-1}$ application gave significantly lower grain yield than bed planting with 100 and $120 \mathrm{~kg} \mathrm{~N} \mathrm{ha}^{-1}$, that was comparable with $80 \mathrm{~kg} \mathrm{~N}^{-1}$ application in bed planting and higher than that of $60 \mathrm{~kg} \mathrm{~N}$ $\mathrm{ha}^{-1}$. This result revealed that wheat yield could be raised by using bed planting method with similar dose of $\mathrm{N}\left(100 \mathrm{~kg} \mathrm{ha}^{-1}\right)$ and at least $20 \mathrm{~kg} \mathrm{~N} \mathrm{ha}^{-1}(20 \%)$ could be saved over conventional method without yield loss in farmers' field condition, though the $\mathrm{N}$ saving was higher in Gazipur site. The yield increase in bed planting with 80,100 and $120 \mathrm{~kg} \mathrm{~N}^{-1}$ over $100 \mathrm{~kg} \mathrm{~N} \mathrm{ha}^{-1}$ in conventional were 10, 20 and 23\%, respectively. Like Gazipur location, the highest grain yield was recorded with $120 \mathrm{~kg} \mathrm{~N} \mathrm{ha}^{-1}$ application in bed planting. 
Table 1. Effect of nitrogen rate on the yield and yield components of wheat under bed planting in rice-wheat cropping system at Gazipur and Chuadanga

\begin{tabular}{|c|c|c|c|c|c|c|c|c|}
\hline \multirow{2}{*}{$\begin{array}{l}\text { Nitrogen rate } \\
\left(\mathrm{N} \mathrm{kg} \mathrm{ha}^{-1}\right)\end{array}$} & \multicolumn{4}{|c|}{ Gazipur } & \multicolumn{4}{|c|}{ Chuadanga } \\
\hline & $\begin{array}{l}\text { Grain } \\
\text { yield } \\
\left(\mathrm{t} \mathrm{ha}^{-1}\right)\end{array}$ & $\begin{array}{c}\text { Panicles } \\
\mathrm{m}^{-2} \\
\text { (no.) }\end{array}$ & $\begin{array}{c}\text { Grains } \\
\text { panicle }^{-1} \\
\text { (no.) }\end{array}$ & $\begin{array}{c}1000- \\
\text { grain wt. } \\
\text { (g) }\end{array}$ & $\begin{array}{l}\text { Grain } \\
\text { yield } \\
\left(\mathrm{t} \mathrm{ha}^{-1}\right)\end{array}$ & $\begin{array}{c}\text { Panicles } \\
\mathrm{m}^{-2} \\
\text { (no.) }\end{array}$ & $\begin{array}{c}\text { Grains } \\
\text { panicle } \\
\text { (no.) }\end{array}$ & $\begin{array}{c}\text { 1000- } \\
\text { grain } \\
\text { wt. (g) }\end{array}$ \\
\hline Bed 0 (Control) & $0.80 \mathrm{c}$ & $174 \mathrm{~d}$ & $14.8 \mathrm{c}$ & $36.8 \mathrm{~b}$ & $0.90 \mathrm{~d}$ & $178 d$ & $15.3 d$ & $35.9 \mathrm{~b}$ \\
\hline Bed 60 & $2.17 \mathrm{~b}$ & $270 \mathrm{~b}$ & $32.4 \mathrm{a}$ & $42.3 \mathrm{a}$ & $2.52 \mathrm{c}$ & $279 c$ & $32.7 \mathrm{~b}$ & $41.5 \mathrm{a}$ \\
\hline Bed 80 & $\begin{array}{l}2.75 \mathrm{a} \\
(21)^{\star}\end{array}$ & $280 \mathrm{~b}$ & $33.9 \mathrm{a}$ & $42.6 \mathrm{a}$ & $\begin{array}{c}2.92 \mathrm{ab} \\
(10)\end{array}$ & 292 bc & $35.3 \mathrm{a}$ & $41.8 \mathrm{a}$ \\
\hline Bed 100 & $\begin{array}{c}2.93 \mathrm{a} \\
(29)\end{array}$ & $319 a$ & $34.9 \mathrm{a}$ & $42.0 \mathrm{a}$ & $\begin{array}{c}3.17 \mathrm{a} \\
(20)\end{array}$ & $329 a b$ & $35.0 \mathrm{ab}$ & $42.1 \mathrm{a}$ \\
\hline Bed 120 & $\begin{array}{c}3.05 \mathrm{a} \\
(38)\end{array}$ & $327 \mathrm{a}$ & $35.7 \mathrm{a}$ & $42.7 \mathrm{a}$ & $\begin{array}{c}3.25 \mathrm{a} \\
(23)\end{array}$ & $336 \mathrm{a}$ & $36.7 \mathrm{a}$ & $42.4 \mathrm{a}$ \\
\hline Flat 0 (Control) & $0.78 \mathrm{c}$ & $209 c$ & $12.2 \mathrm{c}$ & $31.5 \mathrm{c}$ & $0.93 \mathrm{~d}$ & $211 d$ & $12.7 \mathrm{e}$ & $32.0 \mathrm{c}$ \\
\hline Flat 100 (Recommended) & $2.28 \mathrm{~b}$ & $316 \mathrm{a}$ & $26.7 \mathrm{~b}$ & $40.9 \mathrm{a}$ & $2.65 \mathrm{bc}$ & $327 a b$ & $27.7 \mathrm{c}$ & $40.5 \mathrm{a}$ \\
\hline CV (\%) & 9.55 & 5.78 & 9.60 & 5.41 & 7.75 & 7.29 & 5.00 & 4.54 \\
\hline
\end{tabular}

Figures in a column followed by different letters differ significantly at $5 \%$ level of probability as per DMRT.

*Figures in the parenthesis are the yield increased (\%) over conventional recommended control $\left(100 \mathrm{~kg} \mathrm{~N} \mathrm{ha}^{-1}\right)$.

The highest number of panicles $\mathrm{m}^{-2}$ was attained with $120 \mathrm{~kg} \mathrm{~N} \mathrm{ha}^{-1}$ application in bed planting, which was statistically identical to that of $100 \mathrm{~kg} \mathrm{~N} \mathrm{ha}^{-1}$ application in both bed and flat and significantly higher than other treatments in both the locations (Table 1). In Gazipur site, the number of panicles $\mathrm{m}^{-2}$ in bed planting with 60 and $80 \mathrm{~kg} \mathrm{~N} \mathrm{ha}^{-1}$ was similar and that were lower than the treatments with $100 \mathrm{~kg} \mathrm{~N} \mathrm{ha}^{-1}$ application in both bed and flat. However, in Chuadanga site, in bed with $80 \mathrm{~kg} \mathrm{~N}^{-1}$ produced similar number of panicles $\mathrm{m}^{-2}$ to $100 \mathrm{~kg} \mathrm{~N}^{-1}$. Even though the $100 \mathrm{~kg} \mathrm{~N} \mathrm{ha}^{-1}$ application in flat was capable to produce similar number of panicles $\mathrm{m}^{-2}$ to bed planting with 80,100 and $120 \mathrm{~kg} \mathrm{~N} \mathrm{ha}^{-1}$, the grain yield was lower because of lower number of grains panicle ${ }^{-1}$ and lower 1000-grain weight. The number of grains panicle ${ }^{-1}$ was significantly higher in bed planting with different doses of $\mathrm{N}$ fertilizer than conventional method with $100 \mathrm{~kg} \mathrm{~N}$ $\mathrm{ha}^{-1}$ in both the locations. The grain weight of wheat also varied with the application of different treatments. Though the bed planting with different doses of $\mathrm{N}$ application and flat with $100 \mathrm{~kg} \mathrm{~N}$ ha ${ }^{1}$ application achieved statistically identical 1000-grain weight, it was lower in flat method.

\section{Grain yield and yield components of transplant Aman rice}

Grain yield and yield components of transplant Aman rice significantly differed with different treatments of nitrogen in bed planting and conventional method in both Gazipur and Chuadanga site. Bed planting with 80,100 and $120 \mathrm{~kg} \mathrm{~N}^{-1}$ and conventional method with $100 \mathrm{~kg} \mathrm{~N} \mathrm{ha}^{-1}$ produced statistically identical grain yield in both the locations (Table 2). The lowest grain yield was recorded by the treatments without $\mathrm{N}$ fertilizer in bed and flat in both the locations.

The number of panicles $\mathrm{m}^{-2}$ of transplant Aman rice also varied due to use of different $\mathrm{N}$ treatments in bed and flat in both the locations. In Gazipur, application of 80,100 and $120 \mathrm{~kg} \mathrm{~N} \mathrm{ha}^{-1}$ in bed gave higher number of panicles $\mathrm{m}^{-2}$ than $100 \mathrm{~kg} \mathrm{~N} \mathrm{ha}^{-1}$ in flat. Whereas in Chuadanga, 80 , 100 and $120 \mathrm{~kg} \mathrm{~N} \mathrm{ha}^{-1}$ in bed and $100 \mathrm{~kg} \mathrm{~N} \mathrm{ha}^{-1}$ in flat gave statistically identical number of panicles $\mathrm{m}^{-2}$. The plots without $\mathrm{N}$ treatments produced lower number of panicles $\mathrm{m}^{-2}$ in both the locations. The difference in number of panicles $\mathrm{m}^{-2}$ corresponded to differences in yields of the respective treatments. Bed planting with 80,100 and $120 \mathrm{~kg} \mathrm{~N}^{-1}$ produced statistically identical number of grains panicle ${ }^{-1}$ in both the locations. The highest number of grains panicle ${ }^{-1}$ was recorded in bed with $80 \mathrm{~kg} \mathrm{~N} \mathrm{ha}^{-1}$ in Gazipur and with $120 \mathrm{~kg} \mathrm{~N} \mathrm{ha}^{-1}$ in Chuadanga, which were significantly higher than that of bed planting with $60 \mathrm{~kg} \mathrm{~N} \mathrm{ha}^{-1}$ and conventional with $100 \mathrm{~kg} \mathrm{~N} \mathrm{ha}^{-1}$. The lowest number of grains panicle ${ }^{-1}$ was found in the plots without $\mathrm{N}$ fertilizer in both the locations. The 1000-grain weight of transplant Aman rice achieved by different treatments did not differ significantly in both the locations. 
Table 2. Effect of nitrogen rate on the yield and yield components of transplant Aman rice under bed planting in rice-wheat cropping system at Gazipur and Chuadanga

\begin{tabular}{|c|c|c|c|c|c|c|c|c|}
\hline \multirow[b]{2}{*}{$\begin{array}{l}\text { Nitrogen rate } \\
\left(\mathrm{N} \mathrm{kg} \mathrm{ha}^{-1}\right)\end{array}$} & \multicolumn{4}{|c|}{ Gazipur } & \multicolumn{4}{|c|}{ Chuadanga } \\
\hline & $\begin{array}{l}\text { Grain } \\
\text { yield } \\
\left(\mathrm{t} \mathrm{ha}^{-1}\right)\end{array}$ & $\begin{array}{c}\text { Panicles } \\
\mathrm{m}^{-2} \\
\text { (no.) }\end{array}$ & $\begin{array}{c}\text { Grains } \\
\text { panicle }^{-1} \\
\text { (no.) }\end{array}$ & $\begin{array}{c}\text { 1000- } \\
\text { grain } \\
\text { wt. (g) }\end{array}$ & $\begin{array}{l}\text { Grain } \\
\text { yield } \\
\left(\mathrm{t} \mathrm{ha}^{-1}\right)\end{array}$ & $\begin{array}{c}\text { Panicles } \\
\mathrm{m}^{-2} \\
\text { (no.) }\end{array}$ & $\begin{array}{c}\text { Grains } \\
\text { panicle } \\
\text { (no.) }\end{array}$ & $\begin{array}{c}1000- \\
\text { grain } \\
\text { wt. (g) }\end{array}$ \\
\hline Bed 0 (Control) & $3.19 \mathrm{c}$ & $181 \mathrm{c}$ & $86 \mathrm{c}$ & 21.1 & $3.01 \mathrm{c}$ & $175 \mathrm{c}$ & $83 d$ & 23.2 \\
\hline Bed 60 & $4.82 \mathrm{~b}$ & $230 \mathrm{a}$ & $112 \mathrm{~b}$ & 21.3 & $4.96 \mathrm{~b}$ & $214 \mathrm{~b}$ & $113 \mathrm{~b}$ & 23.6 \\
\hline Bed 80 & $5.22 \mathrm{a}$ & $234 \mathrm{a}$ & $122 \mathrm{a}$ & 21.2 & $5.30 \mathrm{a}$ & $223 a b$ & $116 a b$ & 23.8 \\
\hline Bed 100 & $5.31 \mathrm{a}$ & $236 \mathrm{a}$ & $119 a b$ & 21.3 & $5.42 \mathrm{a}$ & $227 \mathrm{a}$ & $118 a b$ & 24.1 \\
\hline Bed 120 & $5.42 \mathrm{a}$ & $240 a$ & $118 \mathrm{ab}$ & 21.4 & $5.33 \mathrm{a}$ & $224 a b$ & $120 \mathrm{a}$ & 23.9 \\
\hline Flat 0 (Control) & $3.08 \mathrm{c}$ & $205 b$ & $80 \mathrm{c}$ & 21.0 & $2.89 \mathrm{c}$ & $184 \mathrm{c}$ & $85 d$ & 23.1 \\
\hline Flat 100 (Recommended) & $5.18 \mathrm{a}$ & $237 \mathrm{a}$ & $112 \mathrm{~b}$ & 21.2 & $5.21 \mathrm{a}$ & $230 \mathrm{a}$ & $105 \mathrm{c}$ & 23.7 \\
\hline CV (\%) & 3.48 & 4.52 & 4.47 & 3.47 & 2.84 & 2.67 & 3.03 & 1.85 \\
\hline
\end{tabular}

Figures in a column followed by different letters differ significantly at $5 \%$ level of probability as per DMRT.

\section{Other plant attributes of wheat}

Plant height, panicle length, non-bearing tillers, sterility, straw yield and harvest index of wheat were significantly affected by different rates of $\mathrm{N}$ fertilizer in both the locations (Table 3 ). The plant heights with $60,80,100$ and $120 \mathrm{~kg} \mathrm{~N} \mathrm{ha}^{-1}$ in bed were similar, which were significantly higher than that of $100 \mathrm{~kg} \mathrm{~N} \mathrm{ha}^{-1}$ in flat and the plots without $\mathrm{N}$ fertilizer. In Gazipur, the longest panicle was found in with $120 \mathrm{~kg} \mathrm{~N} \mathrm{ha}^{-1}$, which was statistically identical to those in bed with 60,80 and $100 \mathrm{~kg}$ $\mathrm{N}$ ha ${ }^{-1}$ and significantly higher than that of $100 \mathrm{~kg} \mathrm{~N} \mathrm{ha}^{-1}$ in flat and the plots without $\mathrm{N}$ fertilizer. However, the panicle length of wheat in flat with $100 \mathrm{~kg} \mathrm{~N}^{-1}$ was statistically similar to that of bed with 60 and $80 \mathrm{~kg} \mathrm{~N} \mathrm{ha}^{-1}$. In Chuadanga, the panicle length in bed with 120 and $100 \mathrm{~kg} \mathrm{~N} \mathrm{ha}^{-1}$ was statistically identical. Similarly, panicle length in bed with $100 \mathrm{~kg} \mathrm{~N} \mathrm{ha}^{-1}$ was similar to that of $80 \mathrm{~kg}$ $\mathrm{N}$ ha ${ }^{-1}$ and it was higher than flat with $100 \mathrm{~kg} \mathrm{~N} \mathrm{ha}^{-1}$. The longer panicles in beds with different $\mathrm{N}$ rates obviously helped in getting higher number of grains panicle ${ }^{-1}$ in the corresponding treatments.

Table 3. Effect of nitrogen rate on the growth parameters of wheat under bed planting and conventional method in rice-wheat cropping system at Gazipur and Chuadanga

\begin{tabular}{|c|c|c|c|c|c|c|}
\hline $\begin{array}{c}\text { Nitrogen rate } \\
\left(\mathrm{N} \mathrm{kg} \mathrm{ha}^{-1}\right)\end{array}$ & $\begin{array}{l}\text { Plant height } \\
\text { (cm) }\end{array}$ & $\begin{array}{l}\text { Panicle } \\
\text { length }(\mathrm{cm})\end{array}$ & $\begin{array}{l}\text { Non-bearing } \\
\text { tillers (no. } \mathrm{m}^{-2} \text { ) }\end{array}$ & $\begin{array}{l}\text { Sterility } \\
(\%)\end{array}$ & $\begin{array}{c}\text { Straw yield } \\
\left(\mathrm{t} \mathrm{ha}^{-1}\right)\end{array}$ & $\begin{array}{l}\text { Harvest } \\
\text { index }\end{array}$ \\
\hline & \multicolumn{6}{|c|}{ Gazipur } \\
\hline Bed 0 (Control) & $78.0 \mathrm{c}$ & $7.9 \mathrm{c}$ & $7.7 \mathrm{a}$ & $21.8 \mathrm{a}$ & $2.40 \mathrm{c}$ & $0.25 \mathrm{~b}$ \\
\hline Bed 60 & $95.3 \mathrm{a}$ & $13.1 \mathrm{ab}$ & $3.3 \mathrm{~b}$ & $13.3 \mathrm{c}$ & $4.40 \mathrm{~b}$ & $0.33 \mathrm{a}$ \\
\hline Bed 80 & $96.0 \mathrm{a}$ & $13.4 \mathrm{ab}$ & $2.7 \mathrm{~b}$ & $12.7 \mathrm{c}$ & $4.89 a b$ & $0.36 \mathrm{a}$ \\
\hline Bed 100 & $96.3 \mathrm{a}$ & $13.8 \mathrm{a}$ & $2.7 \mathrm{~b}$ & $12.3 \mathrm{c}$ & $5.21 \mathrm{ab}$ & $0.36 \mathrm{a}$ \\
\hline Bed 120 & $97.4 \mathrm{a}$ & $14.2 \mathrm{a}$ & $3.0 \mathrm{~b}$ & $11.8 \mathrm{c}$ & $5.66 \mathrm{a}$ & $0.35 \mathrm{a}$ \\
\hline Flat 0 (Control) & $76.7 \mathrm{c}$ & $7.1 \mathrm{c}$ & $9.0 \mathrm{a}$ & $23.0 \mathrm{a}$ & $2.47 \mathrm{c}$ & $0.24 \mathrm{~b}$ \\
\hline Flat 100 (Recommended) & $86.3 \mathrm{~b}$ & $12.0 \mathrm{~b}$ & $8.3 \mathrm{a}$ & $17.3 \mathrm{~b}$ & $5.07 \mathrm{ab}$ & $0.31 \mathrm{a}$ \\
\hline \multirow[t]{2}{*}{ CV (\%) } & 1.37 & 6.88 & 18.71 & 7.36 & 4.23 & 7.85 \\
\hline & \multicolumn{6}{|c|}{ Chuadanga } \\
\hline Bed 0 (Control) & $77.2 \mathrm{c}$ & $8.1 \mathrm{~d}$ & $7.3 \mathrm{a}$ & $22.5 \mathrm{a}$ & $2.56 \mathrm{f}$ & $0.26 \mathrm{~d}$ \\
\hline Bed 60 & $95.4 \mathrm{a}$ & $13.1 \mathrm{c}$ & $4.3 \mathrm{~b}$ & $13.7 \mathrm{c}$ & $5.12 \mathrm{~d}$ & $0.33 \mathrm{~b}$ \\
\hline Bed 80 & $96.5 \mathrm{a}$ & $13.5 \mathrm{bc}$ & $3.7 \mathrm{~b}$ & $13.2 \mathrm{c}$ & $5.42 \mathrm{c}$ & $0.35 \mathrm{a}$ \\
\hline Bed 100 & $97.6 \mathrm{a}$ & $14.4 \mathrm{ab}$ & $3.7 \mathrm{~b}$ & $12.8 \mathrm{c}$ & $5.89 \mathrm{~b}$ & $0.35 \mathrm{a}$ \\
\hline Bed 120 & $98.9 \mathrm{a}$ & $14.8 \mathrm{a}$ & $3.3 \mathrm{~b}$ & $12.5 \mathrm{c}$ & $6.04 \mathrm{ab}$ & $0.35 \mathrm{a}$ \\
\hline Flat 0 (Control) & 79.9 c & $7.3 \mathrm{~d}$ & $8.3 \mathrm{a}$ & $23.4 \mathrm{a}$ & $2.92 \mathrm{e}$ & $0.24 \mathrm{~d}$ \\
\hline Flat 100 (Recommended) & $87.4 \mathrm{~b}$ & $12.6 \mathrm{c}$ & $7.7 \mathrm{a}$ & $18.9 \mathrm{~b}$ & $6.18 \mathrm{a}$ & $0.30 \mathrm{c}$ \\
\hline CV (\%) & 2.67 & 5.47 & 19.72 & 5.60 & 2.68 & 6.52 \\
\hline
\end{tabular}

Figures in a column followed by different letters differ significantly at $5 \%$ level of probability as per DMRT. 
The number of non-bearing tillers was reduced by application of $60,80,100$ and $120 \mathrm{~kg} \mathrm{~N}^{-1}$ in bed as compared to flat with $100 \mathrm{~kg} \mathrm{~N}^{-1}$ and without $\mathrm{N}$ in both the locations. Similarly, significantly lower sterility (\%) was recorded in the bed with $60,80,100$ and $120 \mathrm{~kg} \mathrm{~N}^{-1}$ than flat with $100 \mathrm{~kg} \mathrm{~N} \mathrm{ha}^{-1}$ and without N. In Gazipur, statistically identical straw yields were recorded in the treatments in bed with 80,100 and $120 \mathrm{~kg} \mathrm{~N} \mathrm{ha}^{-1}$ and in flat with $100 \mathrm{~kg} \mathrm{~N} \mathrm{ha}^{-1}$. In Chuadanga, the highest straw yield was recorded in flat with $100 \mathrm{~kg} \mathrm{~N} \mathrm{ha}^{-1}$ and it was statistically identical to the bed with $120 \mathrm{~kg} \mathrm{~N} \mathrm{ha}^{-1}$ which was followed by bed with $100 \mathrm{~kg} \mathrm{~N} \mathrm{ha}^{-1}$. In Gazipur, there were no significant differences in harvest indices of $60,80,100$ and $120 \mathrm{~kg} \mathrm{~N} \mathrm{ha}^{-1}$ in bed and $100 \mathrm{~kg} \mathrm{~N} \mathrm{ha}^{-1}$ in flat, though it was generally lower in flat. In Chuadanga, harvest indices of the treatments 80, 100 and $120 \mathrm{~kg} \mathrm{~N} \mathrm{ha}^{-1}$ in bed were similar, and significantly higher than that of other treatments.

\section{Other plant attributes of transplant Aman rice}

Plant height, panicle length, non-bearing tillers, sterility, straw yield and harvest index of transplant Aman rice were also significantly affected by different rates of $\mathrm{N}$ fertilizer in both the locations (Table 4). The plant heights in bed planting with 80,100 and $120 \mathrm{~kg} \mathrm{~N} \mathrm{ha}^{-1}$ were significantly higher than all other treatments in bed planting and conventional method. Like plant height, the panicle length achieved by the treatments in bed planting with 80,100 and $120 \mathrm{~kg} \mathrm{~N} \mathrm{ha}^{-1}$ were similar and significantly higher than rest of the treatments. The smaller panicles were found in the treatments without $\mathrm{N}$ fertilizer in both the locations. The longer panicles in different bed planting treatments might be an advantage of getting higher number of grains panicle ${ }^{-1}$, which positively contributed to the grain yield.

Table 4. Effect of nitrogen rate on the growth parameters of transplant Aman rice under bed planting and conventional method in rice-wheat cropping system at Gazipur and Chuadanga

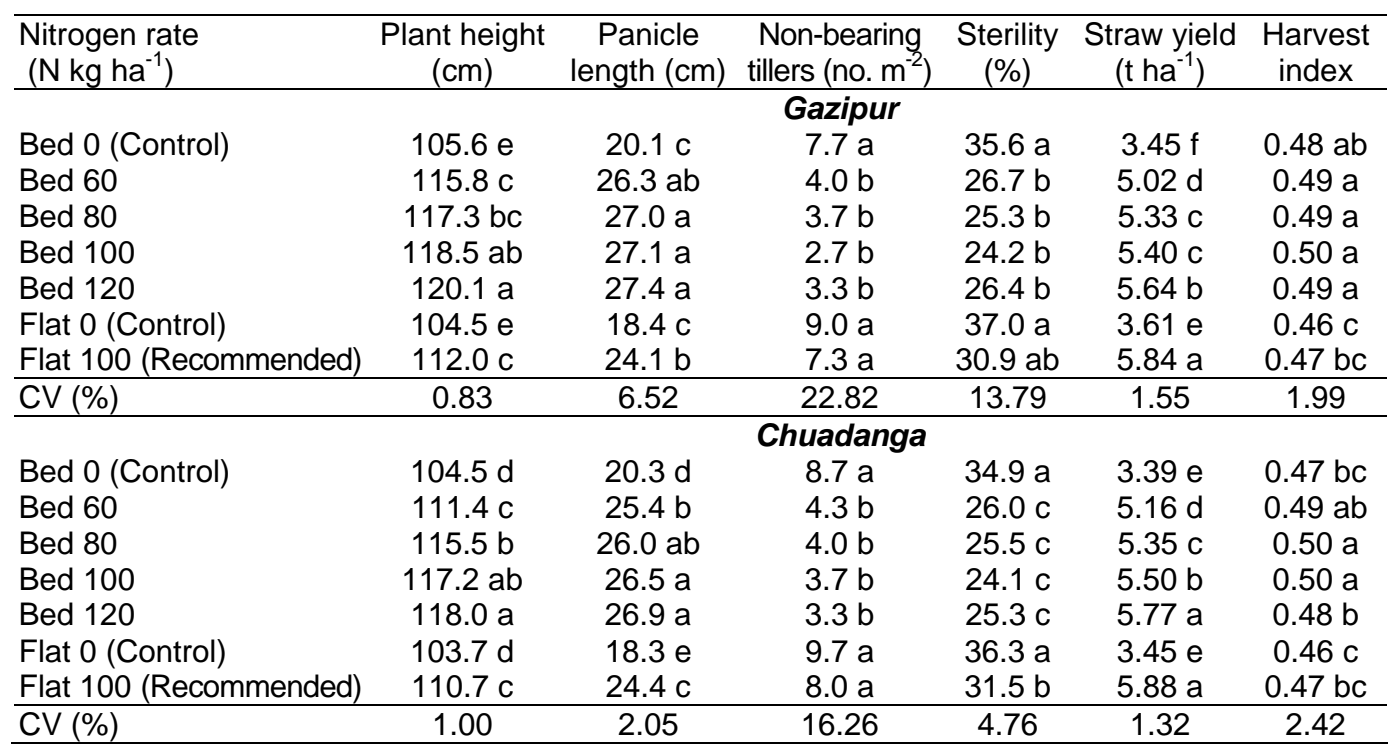

Figures in a column followed by different letters differ significantly at $5 \%$ level of probability as per DMRT.

Number of non-bearing tillers $\mathrm{m}^{-2}$ found in the treatments without $\mathrm{N}$ fertilizer in both bed and flat and $100 \mathrm{~kg} \mathrm{~N} \mathrm{ha}^{-1}$ in flat were statistically identical and those were higher than the treatments $60,80,100$ and $120 \mathrm{~kg} \mathrm{~N} \mathrm{ha}^{-1}$ in bed. The lower number of non-bearing tillers $\mathrm{m}^{-2}$ in beds with different $\mathrm{N}$ rates might be responsible for higher number of panicles in corresponding treatments. Likewise, application of $60,80,100$ and $120 \mathrm{~kg} \mathrm{~N}^{-1}$ in bed reduced sterility percentage. 
Significantly the highest straw yield was recorded in the treatment with $100 \mathrm{~kg} \mathrm{~N} \mathrm{ha}^{-1}$ in flat whereas harvest indices were higher in bed planting with $60,80,100$ and $120 \mathrm{~kg} \mathrm{~N} \mathrm{ha}^{-1}$.

\section{Nitrogen use efficiency for wheat}

The nitrogen use efficiency was compared in terms of partial factor productivity (PFP) and agronomic efficiency (AE). The PFP $\left(\mathrm{kg}_{\text {grain }} \mathrm{kg}^{-1} \mathrm{~N}\right)$ was higher in all bed planting treatments than conventional method with $100 \mathrm{~kg} \mathrm{~N}^{-1}$ at both Gazipur and Chuadanga (Table 5). Bed planting with $60 \mathrm{~kg} \mathrm{~N} \mathrm{ha}^{-1}$ resulted in the highest PFP $\left(36.17-42.00 \mathrm{~kg}\right.$ grain $\left.\mathrm{kg}^{-1} \mathrm{~N}\right)$ and with the increase in $\mathrm{N}$ rate, the PFP was decreased in both the locations.

The $A E$ ( $\mathrm{kg}$ grain increased $\mathrm{kg}^{-1} \mathrm{~N}$ ) was also higher in all bed planting treatments than conventional method with $100 \mathrm{~kg} \mathrm{~N} \mathrm{ha}^{-1}$, whether it was calculated either using the control treatment $\left(0 \mathrm{~kg} \mathrm{~N} \mathrm{ha}^{-1}\right)$ in raised bed or flat method at both the locations. At Gazipur, the highest $\mathrm{AE}$ was recorded in bed planting with $80 \mathrm{~kg} \mathrm{~N} \mathrm{ha}^{-1}\left(24.38-24.63 \mathrm{~kg}\right.$ grain increased $\left.\mathrm{kg}^{-1} \mathrm{~N}\right)$, followed by $60 \mathrm{~kg} \mathrm{~N} \mathrm{ha}^{-1}$ in bed planting and with the increase of $\mathrm{N}$ rate from $80 \mathrm{~kg} \mathrm{ha}^{-1}$, the AE was decreased. In Chuadanga, the highest $A E$ was found in bed planting with $60 \mathrm{~kg} \mathrm{~N} \mathrm{ha}^{-1}(27.00-$ $26.50 \mathrm{~kg}$ grain increased $\mathrm{kg}^{-1} \mathrm{~N}$ ) and with the increase of $\mathrm{N}$ rate the $A E$ was decreased. In Gazipur, the grain yield of wheat with $60 \mathrm{~kg} \mathrm{~N} \mathrm{ha}^{-1}$ was lower than that of Chuadanga, resulting in lower AE to some extent. The results of two locations indicated the advantage of bed panting over conventional method in $\mathrm{N}$ use efficiency. The higher $\mathrm{N}$ use efficiency by bed planting compared to conventional method was also reported by Gupta et al. (2000), Hobbs and Gupta (2003), Hobbs and Sayre (2003), Conor et al. (2003b), Meisner et al. (2005), Ram et al. (2005) and Sayre et al. (2005).

Table 5. Partial factor productivity (PFP) and Agronomic efficiency (AE) of nitrogen use of wheat under bed and conventional planting with different nitrogen rates, Gazipur and Chuadanga

\begin{tabular}{|c|c|c|c|c|c|c|}
\hline \multirow{3}{*}{$\begin{array}{l}\text { Nitrogen rate } \\
\left(\mathrm{N} \mathrm{kg} \mathrm{ha}^{-1}\right)\end{array}$} & \multirow{2}{*}{\multicolumn{2}{|c|}{ PFP $\left(\mathrm{kg}\right.$ grain $\left.\mathrm{kg}^{-1} \mathrm{~N}\right)$}} & \multicolumn{4}{|c|}{$\mathrm{AE}\left(\mathrm{kg}\right.$ grain increased $\left.\mathrm{kg}^{-1} \mathrm{~N}\right)$} \\
\hline & & & \multicolumn{2}{|c|}{ Using $0 \mathrm{~N}$ in bed } & \multicolumn{2}{|c|}{ Using $0 \mathrm{~N}$ in flat } \\
\hline & Gazipur & Chuadanga & Gazipur & Chuadanga & Gazipur & Chuadanga \\
\hline Bed 0 (Control) & & 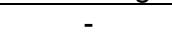 & & - & & - \\
\hline Bed 60 & 36.17 & 42.00 & 22.83 & 27.00 & 23.17 & 26.50 \\
\hline Bed 80 & 34.38 & 36.50 & 24.38 & 25.25 & 24.63 & 24.88 \\
\hline Bed 100 & 29.30 & 31.70 & 21.30 & 22.70 & 21.50 & 22.40 \\
\hline Bed 120 & 25.42 & 27.08 & 18.75 & 19.58 & 18.92 & 19.33 \\
\hline Flat 0 (Control) & - & - & - & - & - & - \\
\hline Flat 100 (Recommended) & 22.80 & 26.50 & 14.80 & 17.50 & 15.00 & 17.20 \\
\hline
\end{tabular}

\section{Nitrogen use efficiency for transplant Aman rice}

For transplant Aman rice, bed planting with 60,80 , and $100 \mathrm{~kg} \mathrm{~N} \mathrm{ha}^{-1}$ resulted in higher PFP than conventional method with $100 \mathrm{~kg} \mathrm{~N}^{-1}$ at both the locations. However, bed planting with $120 \mathrm{~kg} \mathrm{~N}$ $\mathrm{ha}^{-1}$ recorded the lowest PFP at each location (Table 6). The highest PFP was recorded in bed planting with $60 \mathrm{~kg} \mathrm{~N} \mathrm{ha}^{-1}\left(80.33-82.67 \mathrm{~kg}\right.$ grain $\left.\mathrm{kg}^{-1} \mathrm{~N}\right)$ and with the increase in $\mathrm{N}$ rate, the PFP was decreased at every location.

The AE calculated either using the control treatment $\left(0 \mathrm{~kg} \mathrm{~N} \mathrm{ha}^{-1}\right)$ of raised bed or flat method, followed similar pattern. The AE of conventional method with100 $\mathrm{kg} \mathrm{N} \mathrm{ha}^{-1}$ was considerably lower than bed planting with 60,80 and $100 \mathrm{~kg} \mathrm{~N} \mathrm{ha}^{-1}$ but higher than $120 \mathrm{~kg} \mathrm{~N} \mathrm{ha}^{-1}$ at each location. The highest $A E$ was resulted in bed planting with $60 \mathrm{~kg} \mathrm{~N}^{-1}$ at both Gazipur $(27.17-29.00 \mathrm{~kg}$ grain increased $\mathrm{kg}^{-1} \mathrm{~N}$ ) and Chuadanga (32.50 - $34.50 \mathrm{~kg}$ grain increased $\left.\mathrm{kg}^{-1} \mathrm{~N}\right)$. With the increase in $\mathrm{N}$ rate, the $\mathrm{AE}$ was decreased at every location. From the results of two locations it was revealed that the bed planting system could use $\mathrm{N}$ more efficiently than conventional method. 
M. I. U. Mollah et al.

Table 6. Partial factor productivity (PFP) and Agronomic efficiency (AE) of nitrogen use of transplant Aman rice under bed and conventional planting with different nitrogen rates, Gazipur and Chuadanga

\begin{tabular}{|c|c|c|c|c|c|c|}
\hline \multirow{3}{*}{$\begin{array}{l}\text { Nitrogen rate } \\
\left(\mathrm{N} \mathrm{kg} \mathrm{ha}^{-1}\right)\end{array}$} & \multirow{2}{*}{\multicolumn{2}{|c|}{ PFP $\left(k g\right.$ grain $\left.\mathrm{kg}^{-1} \mathrm{~N}\right)$}} & \multicolumn{4}{|c|}{$\mathrm{AE}\left(\mathrm{kg}\right.$ grain increased $\left.\mathrm{kg}^{-1} \mathrm{~N}\right)$} \\
\hline & & & \multicolumn{2}{|c|}{ Using $0 \mathrm{~N}$ in bed } & \multicolumn{2}{|c|}{ Using $0 \mathrm{~N}$ in flat } \\
\hline & Gazipur & Chuadanga & Gazipur & Chuadanga & Gazipur & Chuadanga \\
\hline Bed 0 (Control) & - & - & - & - & - & - \\
\hline Bed 60 & 80.33 & 82.67 & 27.17 & 32.50 & 29.00 & 34.50 \\
\hline Bed 80 & 65.25 & 66.25 & 25.38 & 28.63 & 26.75 & 30.13 \\
\hline Bed 100 & 53.10 & 54.20 & 21.20 & 24.10 & 22.30 & 25.30 \\
\hline Bed 120 & 45.17 & 44.42 & 18.58 & 19.33 & 19.50 & 20.33 \\
\hline Flat 0 (Control) & - & - & - & - & - & - \\
\hline Flat 100 (Recommended) & 51.80 & 52.10 & 19.90 & 22.00 & 21.00 & 23.20 \\
\hline
\end{tabular}

\section{CONCLUSION}

From the results of two locations it could be obviously concluded that $10-38 \%$ grain yield of wheat could be increased by bed planting method over conventional method and $20-40 \% \mathrm{~N}$ could be saved without yield loss. For transplant Aman rice, $20 \% \mathrm{~N}$ could be saved without losing yield. These savings were attained due to higher $\mathrm{N}$ use efficiency of both the crops in bed planting method than conventional method.

\section{LITERATURE CITED}

Aggarwal, P. K., Talukdar, K. K. and Mall, R. K. 2000. Potential yields of rice-wheat system in the Indo-Gangetic Plains of India. Rice-Wheat Consortium Paper Ser. 10. Rice-Wheat Consortium for the Indo-Gangetic Plains. New Delhi, India.

Benites, J. R. 2001. Socio-economic perspectives, policy implications and food security for conservation agriculture in Asia. Presented in Intl. Workshop on Conservation Agriculture for Food Security and Environment Protection in Rice-Wheat Cropping Systems. 6-9 Feb. 2001. Lahore, Pakistan.

BBS (Bangladesh Bureau of Statistics). 2007. 2006 Statistical Yearbook of Bangladesh. Bangladesh Bur. Stat., Stat. Divn., Mini. Plan. Dhaka, Bangladesh. 408 p.

Connor, D. J., Timsina, J. and Humphreys, E. 2003a. Prospects for permanent beds for the ricewheat system. In: Improving Productivity and Sustainability of Rice-Wheat Systems: Issues and Impact. American Soc. Agron. Spec. Publ. 65, 197-210.

Connor, D. J., Gupta, R. K., Hobbs, P. R. and Sayre, K. D. 2003b. Bed planting in rice-wheat systems. In: Addressing Resource Conservation Issues in Rice-Wheat Systems of South Asia: A Resource Book. Rice-Wheat Consortium for the Indo-Gangetic Plains. Intl. Maize and Wheat Impr. Cent., New Delhi, India. pp. 103-108.

Gupta, R. K., Hobbs, P. R., Salim, M., Malik, R. K., Varma, M. R., Pokharel, T. P., Thakur, T. C. and Tripathri, J. 2000. Research and extension issues for farm-level impact on the productivity on rice-wheat systems in the Indo-Gangetic Plains of India and Pakistan. Rice-Wheat Consortium Sem. Rep. Ser. 1. Rice-Wheat Consortium for the Indo-Gangetic Plains. New Delhi, India. 26 p.

Gupta, R. K., Listman, G. M. and Harrington, L. 2003. The Rice-Wheat Consortium for the IndoGangetic Plains: Vision and management structure. In: Addressing Resource Conservation Issues in Rice-Wheat Systems of South Asia: A Resource Book. Rice-Wheat Consortium 
Hobbs, P. R. 2003. New tillage practice for South Asia: Plowing less to save water and slow global warming. In: Bed Planting Training Course 2003. 19 May -21 Jun., 2003. Intl. Maize and Wheat Impr. Cent., Mexico D. F., 06600, Mexico.

Hobbs, P. R. and Gupta, R. K. 2003. Resource-conserving technologies for wheat in the rice-wheat system. In: Improving Productivity and Sustainability of Rice-Wheat Systems: Issues and Impact. American Soc. Agron. Spec. Publ. 65, 149-171.

Hobbs, P. R. and Sayre, K. D. 2003. Resource Conserving Technology. In: Bed Planting Training Course. 19 May -21 Jun. 2003. Intl. Maize and Wheat Impr. Cent., Mexico D. F., 06600, Mexico.

Limon-Ortega A, Sayre, K. D. and Francis, C. A. 2000. Wheat nitrogen use efficiency in a bed planting system in Northwest Mexico. Agron. J. 92, 303-308.

Meisner, C. A., Talukdar, H. M., Hossain, I., Gill, M., Rahmen, H. M., Baksh, E., Justice, S. and Sayre, K. D. 2005. Introduction and implementing a permanent bed system in the rice-wheat cropping pattern in Bangladesh and Pakistan. Presented in ACIAR Workshop on Permanent Bed Planting Systems. 1-3 Mar. 2005. Griffith, NSW, Australia.

Ram. H, Singh, Y., Kler, D.S., Kumar, K., Humphreys, L. and Timsina, J. 2005. Performance of non-rice crops and alternative cropping systems on permanent raised beds in the IndoGangetic plains of north-western India. Presented in ACIAR Workshop on Permanent Bed Planting Systems. 1-3 Mar. 2005. Griffith, NSW, Australia.

Sayre, K. D., Limon, A. and Govaerts, B. 2005. Experiences with permanent bed planting systems, CIMMYT/Mexico. Presented in ACIAR Workshop on Permanent Bed Planting Systems. 1-3 Mar. 2005, Griffith, NSW, Australia. 